\title{
THE HEAVILY INDEBTED POOR COUNTRIES (HIPC) INITIATIVE FUND MICRO-CREDIT AND POVERTY REDUCTION IN GHANA: A PANACEA OR A MIRAGE?
}

\author{
A. K. Osei-Fosu \\ Department of Economics, \\ Kwame Nkrumah University of Science and Technology, Kumasi, Ghana
}

\begin{abstract}
Since Ghana opted for the HIPC debt relief initiative and reached the completion point in June 2004 the country has received several billions of money into the HIPC account at the Bank of Ghana. Part of the funds has been given out in the form of micro-credit to poor households to help reduce their poverty situation. However, there are so many controversies surrounding the HIPC initiative and its benefit, especially, the impact on the incomes of the poor. It was therefore necessary to assess the impact of the micro-credit, especially how it has positively increased, if any, the income levels and therefore reduced the poverty rate. The basic hypothesis was that HIPC initiative fund micro-credit has reduced level and intensity of poverty among beneficiaries. The study was confined to Nkoranza and Wenchi districts, which have successfully maintained the HIPC Micro Credit Scheme. The Foster-Greer-Thorbecko (FGT) Index was used to measure the Head Count Ratio (HCR), Poverty Gap Index (PGI) and the Squared Poverty Gap (SPG), which assess, respectively, proportion of the population under the poverty line, depth of poverty and the severity of poverty. The study came out that incomes have been increased by an average of $26.72 \%$ and $25.50 \%$ for Nkoranza and Wenchi districts, respectively. Again, the study found that over the HIPC implementation period the number of people below the poverty line dropped from 78 to 62 and from 79 to 64 for Nkoranza and Wenchi districts, respectively, making 20.51 and 18.99 percentage point decrease for Nkoranza and Wenchi districts. Comparing PGI of the two years it was found that the cash transfer needed to lift the individuals above the poverty line decreased from 26.47 to 17.20 leading to $35.02 \%$ fall for Nkoranza and from 26.41 to 17.26 leading to 30.30\% for Wenchi. This shows that people in the two districts were nearer the poverty line in 2004 than in the year 2000. This means that people are moving from hard core poverty zones. The results of the SPG of 7.49 and 7.44 for Nkoranza and Wenchi in 2004 against 13.66 and $17.26 \%$ in 2000, respectively, show that poverty intensity has also dropped by $45.45 \%$ and 55.56 for Nkoranza and Wenchi, respectively. Hence, the HIPC micro-credit is a panacea to poverty reduction.
\end{abstract}

Keywords: Heavily Indebted Poor Countries (HIPC), Poverty, Head Count, Poverty Gap, Squared Poverty Gap, Micro-credit

94 Journal of Science and Technology, Vol. 28, No. 3, Dec., 2008 


\section{INTRODUCTION}

During the late 1970s and early 1980s, several dozen developing countries, including a large number of very poor countries, fell into serious sovereign debt crises. And although debt service burdens were rising, inflation-adjusted foreign assistance per capita in the recipient countries was declining. The squeeze of rising debt burdens and falling aid levels threw a large number of poor countries into persistent stagnation or economic decline.

Since the debt crisis in these years, the international financial community has been providing help to debt countries to reduce their external debt burdens in order to attain debt sustainability, reduce poverty and above all achieve economic growth. This assistance, in the form of debt relief, has evolved over the years. Today many countries, especially those in the subSaharan Africa continue to suffer from unfavorable terms of trade and worsening economic conditions, leading to unacceptable poverty levels and huge and unsustainable external debt burdens. It was against this background that the HIPC Initiative was first launched in 1996 by the IMF and the World Bank, with the aimed of reducing the external debt burdens of qualified and eligible countries to a sustainable level within a specified period of time so that no poor country faces a debt burden it cannot manage. This was meant to reduce the constraints on economic growth as well as reduce poverty caused by the debt build-up in these countries. The Initiative was modified in 1999 (into the Enhanced HIPC), to provide fast, deeper and broader relief by increasing the number of eligible countries, raising the amount of relief each eligible country will receive as well as providing a stronger link between debt relief and poverty reduction. Bilateral creditors including all the G8 countries also announced, in support of the Initiative, to provide $100 \%$ debt cancellation for all HIPC countries.

The war against poverty is being fought in recent years at various fronts. The Government com- mitted itself to a systematic reduction of poverty through the implementation of the Ghana Poverty Reduction Strategy with the support from the HIPC Relief Fund. Since Ghana opted for the HIPC debt relief initiative in March 2001 and reached decision point in February 2002, and the completion point in June, 2004, the country has received a total amount of about GHф221.10 million into the HIPC account at the Bank of Ghana. Government has disbursed a total of $\mathrm{GH} \propto 111.76$ million from the HIPC Account to support poverty-related spending by the Ministries, Departments and Agencies (MDAs), metropolitan, Municipal and District Assemblies. For the first half of 2004 alone, a total amount of about GHф73.4 million was spent (as at end June 2004). These HIPC relief resources were purported to be used to improve education and health services delivery, speed up rural electrification, and enhance rural agriculture, feeder roads construction and rehabilitation, rural water and sanitation, among others (Osafo-Marfo, 2004).

Part of the HIPC funds has been given out in the form of micro-credit to poor households to help reduce their poverty situation. However, there are so many controversies and arguments surrounding the HIPC initiative and its benefit, especially, the impact on the incomes of the poor. It was therefore necessary to assess the impact of the micro-credit, especially how it has positively increased, if any, the income levels and therefore reduced the poverty rate. The basic hypothesis tested was; the HIPC initiative fund micro-credit has reduced level and intensity of poverty in the beneficiary communities.

The specific objective was to assess the impact, if any, of the HIPC micro-credit on poverty reduction. It is the belief that the results will help to clear minds of people about the effectiveness of the HIPC micro-credit on poverty reduction. The results are also guide to policy makers about the distribution of the HIPC funds for the GPRS II. 


\section{MATERIALS AND METHODS}

\section{Data Source}

Considering limitedness of resources, the study was confined to only two districts, Nkoranza and Wenchi, all in the Brong Ahafo Region, who have benefited from HIPC funded projects and successfully maintained the Micro Credit Scheme since Ghana opted for HIPC. These two districts share the same characteristics in terms of the occupation, income levels, and poverty index. The households in these two districts are basically farmers, with low income levels. The two homogenous districts were used to facilitate comparison.

The study employed basically primary data in its analysis. The study used interviews and questionnaires to collect primary data. The sources of the data were communities that have benefited from HIPC initiative funds.

The unit of analysis was households. Household in the analysis refers to a family that shares the same bow, with a head whose income was used. These were residents of the communities where the funds have been implemented and projects financed from the HIPC fund and also have maintained the micro-credit scheme of the HIPC initiative fund. In all 400 households were used for the study, 200 from each district. In each district they included 100 households who benefited from the Micro-credit and 100 nonbeneficiaries who were randomly selected from 10 communities (10 of the two groups from each community). In each of the communities, a list of the households who benefited from the Micro -credit was obtained and 10 were taken out randomly for interview and questionnaire administration.

\section{Definition of Variables}

The main data for the study were incomes. Because the respondents were farmers and do not earn regular daily or monthly incomes, their yearly incomes were estimated and divided by 365 days to determine their respective daily income. The incomes used referred to the monetary value of all their produce from their farming activities within the year. For the purpose of intra-comparison, and to do away with effects of price changes, the 2004 year prices were used for the estimation of the household's income for both 2000 and 2004. Since constant 2004 year prices were used, the study also used the 2004 Dollar rate of approximately $\mathrm{GH} \varnothing 0.94$ as the poverty line income for 2000 and 2004. Again, to account for other factors that can affect the people's incomes besides the micro-credit, the incomes of the beneficiaries of the micro-credit are compared with the incomes of those who did not benefit from the micro-credit within each district. The three FGT methods of assessing poverty were used. The study also did comparative analysis by comparing the poverty levels before the HIPC initiative and after the initiative. Theoretically, poverty may be defined in two ways; absolute terms and relative terms. Absolute poverty was defined by UN (1995) as "a condition characterized by severe deprivation of basic human needs; including food, safe drinking water, sanitation facilities, health, shelter, education and information. Relative poverty on the other hand refers to those deprived relative to others around them. For the purpose of this study the absolute poverty definition is used. This is due to the fact that majority of the population live below the poverty line and the concern of the HIPC and the Poverty Reduction strategy was aimed at this category. Again, there are three dimension of poverty, viewed from the two angles; income or consumption, lack of basic social amenities, and lack of opportunity to contribute to political issues and decisions of the nation. Here the study concentrates on the income or consumption dimension, for which data are easier to acquire and directly related to poverty.

Under this, the Foster-Greer-Thorbecko (FGT) Index was used to measure the Head Count Ratio (HCR), Poverty Gap Index (PGI) and the Squared Poverty Gap (SPG), which assess, respectively, proportion of the population under the poverty line, depth of poverty and the severity of poverty (Foster et al., 1984). The model is as follows;

96 Journal of Science and Technology, Vol. 28, No. 3, Dec., 2008 


$$
\mathrm{FGT}=\frac{1}{n} \sum_{i=1}^{q}\left(\frac{z-y_{i}}{z}\right)^{\alpha}
$$

where,

$\mathrm{n}=$ the number of sample household or individual,

$\mathrm{z}=$ the estimate of the poverty line income,

$\mathrm{i}=1,2,3, \ldots$, qth household or individual whose incomes are below the poverty line,

$\mathrm{y}=$ the income of the household or individual among the poor, and

$\alpha=$ weight society gives to the poverty problem (poverty aversion parameter), for $\alpha, 0 \leq \alpha \leq \infty$.

This implies that the FGT poverty measure is distributive sensitive within the poor group. The parameter $\alpha, 0 \leq \alpha \leq \infty$, indicates the degree of aversion to poverty such that as $\alpha$ increases there is increasing weight given to the poorest household. When $\alpha=0$, the implication is that society wants to know only the number of poor below the poverty line within a given population (Head Count Measure of Poverty or Poverty Rate). Head Count Measure of Poverty or Poverty Rate,

$$
P_{0}=\frac{Q}{n}
$$

represents the proportion of the population that is poor. Given a poverty line $\mathrm{z}$, a person is poor if $\mathrm{y}<\mathrm{z}$. Given $\alpha \geq 1$ means society is interested in distinguishing among the poor. Where $\alpha=1$, each poor is weighted by his or her relative distance, from the person who is nearer the poverty line and the same incremental income accruing to the person who is further away from the poverty line. In this case, the poverty measure reduces to a measure of the aggregate poverty gap $\left(P_{I}\right)$ and shows the proportion of total income needed to be transferred from the non-poor to the poor household to lift them above the poverty line. That is, the aggregate poverty gap is measured as

$$
g=\sum_{q=1}^{Q} \max \left(\frac{z-y_{q}}{z} 0\right), \text { for } Q \leq n,
$$

which reflect income deficit as a proportion of the poverty line income among the poor population. The average poverty gap is then found either by dividing the aggregate by the total population if the interest is in the average gap among the whole society,

$$
\text { i.e } \frac{g}{n}
$$

or by dividing by the total poor to yield the poverty gap per poor person

i.e $\frac{g}{Q}$

If society is particularly averse to inequality among the poor, the poverty measure must give higher weight to an income transfer to the poorer compared with a less poor household. Thus, the value of $\alpha$ must be more than unity.

When $\alpha=2$, Squared Poverty Gap, measures the intensity or severity of poverty. While the Poverty Gap Index takes into account the distance separating the poor from the poverty line, the Squared Poverty Gap takes the square of the distance into account i.e. the poverty gap is weighted by itself, so as to give more weight to the very poor. This accounts for the inequality among the poor.

Kakwani (1980) and Sen (1981) have proposed several criteria that a poverty measure must satisfy to be able to assess the changes in social welfare. First an increase in income of person below the poverty line, with the incomes of others unchanged. Secondly, when there is a transfer of incomes from the rich to the poor without a change in the poverty line. Third, where there is a good increase in income of persons far below the poverty line than for a person near the 
poverty line. Last, a poverty measure is a characteristic of the poor and not of the general poverty of the nation. Here, for the purpose of simplicity and availability of data, $\alpha=2$ is used to cater for the distributional effect.

\section{RESULTS AND DISCUSSION}

Appendix A and B show the distribution of income of households in Nkoranza and Wenchi employed in the analysis. They also capture the respective percentage changes between incomes in 2000 and 2004. The beneficiaries of the HIPC initiative micro-credit are designated as households A (HA) and the non-beneficiaries as households B (HB). A particular individual respondent in household A or B group is indicated by a number attached.

The data in Appendices show that incomes of the households are re-arrange in ascending order, based on the 2000 incomes. It came out that in Nkoranza the $80^{\text {th }}$ respondent in household $\mathrm{A}$, who had the lowest income in 2000 ( $\mathrm{GH} \varnothing 0.19)$ also had the lowest income in 2004 ( $\mathrm{GH} \phi 0.23$ ), and the $77^{\text {th }}$ had both the highest income in 2000 and 2004 (GHф2.00 and $\mathrm{GH} \phi 2.60$, respectively). In the case of Wenchi, the household $56^{\text {th }}$ had the lowest income in 2000 and 2004 (GH $\phi 0.19$ and $\mathrm{GH} \phi 0.20$, respectively) and the household $44^{\text {th }}$ had the highest in 2000 and 2004 (GH $\varnothing 1.60$ and $\mathrm{GH} \notin 2.20$, respectively). Again, it can be observed that every individual in household A had a positive percentage change in his or her income between 2000 and 2004 for the two districts. The percentage increases in the incomes range between 4.44 and 50 for Nkoranza, and between 2.56 and 65.00 for Wenchi. The mean percentage changes were $26.72 \%$ and $25.50 \%$, for Nkoranza and Wenchi, respectively.

The same cannot be said about household B. Here, some individual had negative changes in their incomes between 2000 and 2004 for the two districts. The range of change was between $4.17 \%$ and $22.78 \%$ for Nkoranza and -8.57 and 27.00 for Wenchi. It is therefore clear that those who benefited from the HIPC micro-credit were able to improve upon their incomes between 2000 and 2004 for the two districts. Hence, the conclusion is that the HIPC initiative microcredit has had positive impact on poverty reduction in the study areas.

\section{Measure of Head Count Index}

Table 1 is the estimates on Head Count Index derived from appendix A. It covers the Head Count Indices for the two households in the two years for the two districts.

About 78 and 79 households in Nkoranza and Wenchi respectively for both household categories had incomes below the poverty line before the HIPC initiative in 2000. This indicates a Head Count Index of 78 in each group for Nkoranza and 79 in each group for Wenchi. In the case of Nkoranza this figure came down to 62 for household A representing $20.51 \%$ reduction in the number of poor people in 2004. There was also $18.99 \%$ reduction Wenchi. This cannot be said of household B whose Head Count Index reduced to 76 representing only $2.56 \%$ reduction

Table 1: Estimated Head Count Index

\begin{tabular}{lcccc}
\hline \multicolumn{1}{c}{ Head Count Indices } & \multicolumn{2}{c}{ Households A } & \multicolumn{2}{c}{ Households B } \\
& Nkoranza & Wenchi & Nkoranza & Wenchi \\
\hline Head Count Index (HCI) for 2000 & 78 & 79 & 78 & 79 \\
Head Count Index for (HCI)2004 & 62 & 64 & 76 & 75 \\
Percentage Decrease in HCI & 20.51 & 18.99 & 2.56 & 5.06 \\
\hline Source: Author's Survey & & & \\
\hline
\end{tabular}

98 Journal of Science and Technology, Vol. 28, No. 3, Dec., 2008 
Table 2: Estimated Poverty Gap Index

\begin{tabular}{lrrrr}
\hline \multicolumn{1}{c}{ Poverty Gap Indices } & \multicolumn{2}{c}{$\begin{array}{c}\text { Households A } \\
\text { Nkoranza Wenchi }\end{array}$} & \multicolumn{2}{c}{$\begin{array}{c}\text { Households B } \\
\text { Nkoranza Wenchi }\end{array}$} \\
\hline Aggregate Poverty Gap for 2000 & 26.47 & 26.41 & 22.56 & 20.16 \\
Poverty Gap Index for 2000 & 0.43 & 0.33 & 0.29 & 0.26 \\
Aggregate poverty Gap for 2004 & 17.20 & 13.85 & 20.19 & 18.08 \\
Poverty Gap Index for 2004 & 0.28 & 0.23 & 0.27 & 0.24 \\
Percentage decrease in Poverty Gap Index & 34.88 & 30.30 & 6.90 & 7.69 \\
\hline
\end{tabular}

Source: Author's Survey

in the poverty rate in Nkoranza and $5.06 \%$ in Wenchi. This again lends credence to the fact that the HIPC initiative micro-credit has helped to push many poor above the poverty line.

\section{Measure of Poverty Gap Index (PGI)}

Table 2 portrays the Aggregate Poverty Gap, Poverty Gap Index and the percentage decrease between 2000 and 2004 for the two groups of households.

The results from Table 2 indicate that the aggregate poverty gap income was 26.47 and 26.41 for Nkoranza and Wenchi, respectively of the poverty line income in 2000 for household A, giving the Poverty Gap Index of 0.43 and 0.33 for Nkoranza and Wenchi, respectively. This implies that in 2000, before the implementation of the HIPC initiative micro-credit, the aggregate income deficit among the poor population i.e. the amount needed to transfer to the 78 and 79 poor for Nkoranza and Wenchi, respectively were $\mathrm{GH} \phi 24.78$ and $\mathrm{GH} \phi 19.02$, respectively. This therefore gives an average of GH $\phi 0.32$ and $\mathrm{GH} \phi 0.30$ for Nkoranza and Wenchi, respectively. When compared with household B, the aggregate poverty gap income was 22.56 and 20.16 for Nkoranza and Wenchi, respectively and the Poverty Gap Index as 0.29 and 0.26 respectively. These also gave aggregate income deficit and average of $\mathrm{GH} \phi 21.12$ and $\mathrm{GH} \phi 0.27$ for Nkoranza, respectively and $\mathrm{GH} \phi 18.87$ and

$\mathrm{GH} \notin 0.24$ for Wenchi. The analysis shows that as at 2000 households in group B were relatively closer to the poverty line than households A. This may explain why they might not have been given the micro-credit.

In 2004, the Aggregate Poverty income for household A decreased to 17.20 with the Poverty Gap Index of 0.28 for Nkoranza. This means that there was a percentage decrease of 34.88 of the Poverty Gap Index. It is inferred that the aggregate income deficit in 2004 was $\mathrm{GH} \phi 16.10$ or an average of $\mathrm{GH} \phi 0.26$ (a decrease of $\mathrm{GH} \phi 0.06$ between 2000 and 2004). This was equally the same for Wenchi. The Aggregate Poverty income for household A decreased to 13.85 with the Poverty Gap Index of 0.23 . This gave a percentage decrease of 30.30 , which implies that the aggregate income deficit in 2004 was $\mathrm{GH} \phi$ 13.22 or an average of $\mathrm{GH} \phi 0.21$. When compared to the non-beneficiary group it is clear that the extent of poverty reduction was insignificant. From Table 2 the Aggregate Poverty Income only decreased from 22.56 in 2000 to 20.19 in 2004 and the Poverty Gap Index from 0.29 to 0.27 between the same period (a percentage decrease in the Poverty Gap index of 6.90) for Nkoranza. The situation was the same for Wenchi. The Aggregate Poverty Income only decreased from 20.16 in 2000 to 18.08 in 2004 and the Poverty Gap Index from 0.26 to 0.24 (a percentage decrease in the Poverty Gap index of 7.69). In terms of cedis, the aggregate income deficit and the average income deficit decreased 
from $\mathrm{GH} \phi 21.12$ and $\mathrm{GH} \notin 0.27$, respectively to $\mathrm{GH} \phi 18.10$ and $\mathrm{GH} \phi 0.25$, respectively for Nkoranza. This gives only a reduction of the average poverty of $\mathrm{GH} \phi 0.02$. In Wenchi, the aggregate income deficit and the average income deficit decreased from $\mathrm{GH} \phi 18.87$ and $\mathrm{GH} \phi 0.24$, respectively to $\mathrm{GH} \phi 17.42$ and $\mathrm{GH} \phi 0.23$, respectively. It can therefore be concluded that the HIPC micro-credit has reduced the extent of poverty among the beneficiary groups or moved them relatively closer to the poverty line income.

\section{Measure of Squared Poverty Gap}

As explain above, the Squared Poverty Gap estimates the intensity of poverty among the poor. Table 3 shows the summary of the Squared Poverty Gap for households A and B in 2000 and 2004.

From Table 3, the Square Poverty Gap reduced from 0.22 in 2000 to 0.12 in 2004 for household A in Nkoranza, giving a percentage reduction of 45.45. On the other hand it was 0.13 in 2000 and came down to 0.11 with only $15.38 \%$ decrease in 2004 for household B. Wenchi also followed the same trend. The Square Poverty Gap reduced from 0.27 in 2000 to 0.12 in 2004 for household A, giving a percentage reduction of 55.56 . Again, it was 0.14 in 2000 and came down to 0.10 with only $14.29 \%$ decrease in 2004 for household B. The implication is that the inequal- ity of income among the poor household A was greater than households B in 2000 for both districts and it has now reduced significantly for household A than household B.

\section{Statistical Analysis}

The hypotheses tested and the results are depicted in Table 4. The table highlights on six test results. Using the student t-test, paired sample for means, it came out that there is no significant statistical difference between income distribution of household A and B in 2000 at 5\% level of significance for the two districts. This supports the fact that before the HIPC the two groups had virtually the same level of income in the two districts. At the same significant level there is also no significant difference in incomes of household B between 2000 and 2004, indicating that their incomes have not significantly change in the two districts.

However, there is significance difference between the mean incomes of household A and B in 2004. Hence, the differences in the incomes observed are not attributed to chance but the impact of the HIPC micro-credit. Again, the mean difference in income of household $\mathrm{A}$ between 2000 and 2004 is statistically significant at the same $5 \%$ error level. Finally, the mean difference between households $\mathrm{A}$ and $\mathrm{B}$ in terms of percentage changes and the estimated results

Table 3: Estimated Squared Poverty Gap Index

\begin{tabular}{lcrrr}
\hline Squared Poverty Gap Indices & \multicolumn{2}{c}{ Households A } & \multicolumn{2}{c}{ Households B } \\
Nkoranza Wenchi & Nkoranza Wenchi \\
\hline Aggregate Squared Poverty Gap for 2000 & 13.66 & 17.26 & 10.06 & 11.13 \\
Squared Poverty Gap Index for 2000 & 0.22 & 0.27 & 0.13 & 0.14 \\
Aggregate Squared Poverty Gap for 2004 & 7.49 & 7.44 & 8.29 & 7.76 \\
Squared Poverty Gap Index for 2004 & 0.12 & 0.12 & 0.11 & 0.10 \\
Percentage decrease in Squared Poverty Gap Index & 45.45 & 55.56 & 15.38 & 14.29 \\
\hline
\end{tabular}

Source: Author's Survey

100 Journal of Science and Technology, Vol. 28, No. 3, Dec., 2008 
Table 4: Results of T-Test Paired Two Samples for Means

\begin{tabular}{lcccc}
\hline Hypothesis & $\begin{array}{l}\text { Test } \\
\text { Statistics }\end{array}$ & $\begin{array}{l}\text { Critical Value } \\
\text { two-tail) }\end{array}$ & $\begin{array}{l}\text { Probability } \\
\text { Value(T< t) }\end{array}$ & Conclusion \\
\hline $\begin{array}{l}\text { Mean difference in income } \\
\text { between HA and HB in 2000 }\end{array}$ & -1.6634 & 1.9842 & 0.0990 & Not significant \\
$\begin{array}{l}\text { Mean difference in income of } \\
\text { HB between 2000 and 2004 }\end{array}$ & -1.7539 & 1.9842 & 0.1530 & Not significant \\
$\begin{array}{l}\text { Mean difference in income } \\
\text { between HA and HB in 2004 }\end{array}$ & -7.1267 & 1.9842 & $1.6878 \mathrm{E}-10$ & Significant \\
$\begin{array}{l}\text { Mean difference in income of } \\
\text { HA between 2000 and 2004 }\end{array}$ & -12.1777 & 1.9842 & $2.1412 \mathrm{E}-21$ & Significant \\
$\begin{array}{l}\text { Mean difference between per- } \\
\text { centage change in income of }\end{array}$ & 13.4491 & 1.9842 & $4.5119 \mathrm{E}-24$ & Significant \\
$\begin{array}{l}\text { HA and HB } \\
\begin{array}{l}\text { Mean difference Estimates of } \\
\text { HA and HB }\end{array}\end{array}$ & 2.7468 & 2.1788 & 0.043099 & Significant \\
\hline
\end{tabular}

Source: Author's Survey

are found to be statistically significant. These results imply that the HIPC initiative fund micro -credit scheme has indeed reduced poverty of the beneficiary households in the two districts.

\section{CONCLUSION}

The study has assessed the impact of the HIPC micro-credit on poverty reduction among 400 farm households in Nkoranza and Wenchi Districts of Brong Ahafo Region of Ghana. Using increase in income as a measure of poverty reduction, the study came out that incomes have been increased by an average of $26.72 \%$ and $25.50 \%$ for Nkoranza and Wenchi districts, respectively. Again, the study found that over the HIPC implementation period the number of people below the poverty line dropped from 78 to 62 and from 79 to 64 for Nkoranza and Wenchi districts, respectively, making 20.51 and 18.99 percentage point decrease for Nkoranza and Wenchi districts, respectively. Comparing PGI of the two years indicates that the cash transfer needed to lift the individual households above the poverty line decreased from 26.47 to 17.20 leading to $35.02 \%$ fall for Nkoranza and from 26.41 to 17.26 leading to $30.30 \%$ for Wenchi.
This shows that people in the two districts have come nearer to the poverty line in 2004 than in the year 2000. This means that people are moving from hard core poverty zones. The results of the SPG, 13.66 and 7.49 for Nkoranza and 17.26 and 7.44 for Wenchi, show that poverty intensity has also dropped. This implies that the poorest of the poor has reduced (45.45\% and 55.56 for Nkoranza and Wenchi, respectively). Hence, it is concluded that the HIPC micro-credit has helped to reduce poverty and therefore it is a panacea.

\section{REFERENCES}

Addison, T. and Osei, R. (2000). Taxation and Fiscal Reform in Ghana, Paper Presented at the WIDER Project on New Fiscal Policies for Growth and Poverty Reduction Workshop, Helsinki, 17-18 November.

Bangura, S., Kitabire, D. and Powell, R. (2000). External Debt Management in Low- Income Countries, IMF Working Paper, WP00/196.

Boateng, K., Oduro, A. D. and Boakye-Yiadom, L. (2001). Poverty in Ghana, A Final Report Presented to the African Economic Research Consortium, RP 14 August, 2001. 
Botchwey, J. K., Cuchra, M. and Sievers, S. (1999). Implementing Debt Relief for the HIPC, Centre for International Development, Harvard University, pp. 3-10.

Brownbridge, M., Gockel, A. F. and Harrington, R. (2000). Savings and Investment, in Aryeetey, E., Harrigan and Nissanke, M. (2000). Economic Reforms in Ghana: The Miracle and the Mirage, London, James Currey, pp. 132-149.

Foster, J. and Szekely, M. (2000). How Good is Growth? Asian Development Review 18(2): 59-73.

Fsoter, J., Greer, N. and Thorbecke, E. (1984). Class of Decomposable Poverty Measures, Econometrica 52 (3): 761-766.

Ghana Poverty Reduction Strategy Paper (20032005), An Agenda for Growth and Prosperity, Analysis and Policy Statement, February 19, 2003, 1. Ghana Poverty Reduction Strategy-(Poverty Diagnosis and Component of the Strategy), Ghanaweb.economy. com.
Kakwani, N. (2001). Pro-Poor Growth and Policies, at the ADB Annual Meeting Seminars in Honolulu, Hawaii, pp. 13-18.

Kakwani, N. (2003). Issues in Setting Absolute and Social Development, Development paper, No 3, ADB, Manila, pp. 6-8.

Osei, R. and Quartey, P. (2001). The HIPC Initiative and Poverty Reduction in Ghana: An Assessment, Paper Prepared for the WIDER Conference on Debt Relief, Helsinki 17-18 August, 2001, pp. 4-13.

Simon, M. (2001). The Meaning and Measurement of Poverty, ODI Poverty Briefing, February 12, 2001.

Sen, A.K. (1976). Poverty: An Ordinal Approach to Measurement, Econometrica, 44 (2): 251-256.

Osafo-Marfo, Y. (2004). Ghana Reaching the Completion Point under the Enhanced Highly Indebted Poor Countries Initiative, Daily Graphic, July 20, 2004. 